\title{
CR Research Square \\ A Quality Analysis Of Low Back Pain Videos On Youtube
}

Keywords:

Posted Date: March 1st, 2021

DOI: https://doi.org/10.21203/rs.3.rs-104878/v2

License: (c) (1) This work is licensed under a Creative Commons Attribution 4.0 International License.

Read Full License 


\section{Abstract}

The authors have requested that this preprint be removed from Research Square. 